\title{
Stimulatory effect of short-chain fatty acids on epithelial cell proliferation in the rat intestine: a possible explanation for trophic effects of fermentable fibre, gut microbes and luminal trophic factors*
}

\author{
BY TAKASHI SAKATA \\ Yakult Central Institute for Microbiological Research, \\ Physiology Group, Kunitachi 186, Japan
}

(Received 3 September 1986 - Accepted 23 January 1987)

1. Effects of short-chain fatty acids (SCFA) on epithelial proliferation of the intestine were studied in ileally fistulated rats fed on an elemental diet.

2. The stimulatory effect of daily doses of acetic, propionic and $n$-butyric acids $(100,20$ and $60 \mathrm{~mm}$ respectively; pH 6.1) per fistula ( $3 \mathrm{ml}$, twice daily) on crypt cell production rate (CCPR) appeared within $2 \mathrm{~d}$ and lasted for at least $5 \mathrm{~d}$.

3. The daily doses of SCFA for $14 \mathrm{~d}$ increased daily CCPR three to four fold. This effect was independent of the presence of gut bacteria.

4. Effects of SCFA were dose-dependent and varied among acids (butyrate $>$ propionate $>$ acetate). The effect was independent of low lumen $\mathrm{pH}$.

5. In contrast, SCFA inhibited epithelial proliferation of isolated rat caecal tissue in vitro.

6. These results suggest that SCFA are physiological lumen trophic factors mediated by a systemic mechanism in vivo.

7. It is concluded that SCFA are involved in the trophic effects of gut microbes, ingestion of fermentable fibre, and lumen contents.

Readily fermentable dietary fibre stimulates epithelial proliferation of the intestine, but only in the presence of gut microbes (Komai et al. 1982). End-products of gut fermentation, namely the short-chain fatty acids (SCFA), appear to be responsible for some of the effects of fermentable fibre (Sakata \& Yajima, 1984; Topping \& Illman, 1986).

SCFA stimulate mucosal development (Tamate et al. 1962) and epithelial cell division (Sakata \& Tamate, 1978, 1979; Galfi et al. 1986) in the rumen. SCFA in temporarilyisolated colonic loops stimulate epithelial proliferation in the digestive tract of rats (Sakata \& von Engelhardt, 1983), although nutritional significance of this acute study is unknown.

Preliminary studies showed that daily doses of SCFA for 2 weeks accelerated epithelial proliferation in rat intestine with slight increase in tissue weight (Sakata, 1984, 1986). However, such results should be accepted with caution (Lupton et al. 1985), since SCFA generally inhibit cell proliferation in vitro (Ginsburg et al. 1973; Kruh, 1982).

The present experiments were designed to study the mechanism and possible nutritional significance of the trophic effect of SCFA on the intestinal epithelium in rats.

\section{EXPERIMENTAL METHODS}

\section{Animals}

Male conventional F344/Jcl rats (CLEA Japan, Tokyo) (Expts 1, 2 and 4) or male germfree F344/Yit rats (bred in our institute) (Expt 3) were used for experiments in vivo. An external ileal fistula (Roux-en-Y ileostomy with abdominal opening) was established at

* Part of this study was presented orally at the 39th and 40th meetings of the Japanese Society for Nutritional and Food Science (Tokyo, 27-29 April 1985 and Nagoya, 2-4 May 1986 respectively) and at the 79th meeting of the Japanese Society of Zootechnical Science (Tsukuba, 28-29 March 1986). 
5-6 weeks of age for administration of experimental solutions into the caecum. Surgery was followed by at least $14 \mathrm{~d}$ recovery (Sakata, 1986). The in vitro experiment (Expt 5) employed intact male conventional F344/Jcl rats. Conventional rats were housed in stainless-steel wire-mesh cages, without bedding material, in a controlled environment (Umesaki et al. 1979). Germ-free rats were kept in plastic cages containing sterilized wood shavings and placed in a sterilized vinyl isolator in an environment identical to that for conventional animals.

\section{Feeds}

Rats had free access to feed and water. For Expts 1, 2 and 4 an elemental diet (Elental ${ }^{\circledR}$, Morishita Seiyaku, Osaka) was used to reduce SCFA production. Non-fermentable bulk (kaolin) was added to the elemental diet $(100 \mathrm{~g} / \mathrm{kg})$ (Sakata, 1986). For Expt 5, rats were fed on a commercial pelleted diet (MF; Oriental Yeast, Tokyo). Germ-free rats (Expt 3) were fed on a sterilized commercial diet for germ-free rats (CL-2, CLEA Japan).

\section{Estimation of proliferative activity of the intestinal epithelium}

Crypt cell production rate (CCPR) (Wright \& Appleton, 1980) represented the rate of epithelial cell proliferation. The cell proliferation cycle was arrested at the metaphase of mitosis by colchicine in vivo or in vitro. The dose of colchicine was based on the results of a preliminary dose-response study (T. Sakata, unpublished results). For metaphase arrest in vivo a small piece of intestinal segment was taken for biopsy from anaesthetized rats (Nembutal ${ }^{\circledR} ; 30 \mathrm{mg} / \mathrm{kg}$ intraperitoneally) at $1.5,2.0$ and $2.5 \mathrm{~h}$ after colchicine administration $(4 \mathrm{mg} / \mathrm{kg}$ intraperitoneally). Rats were then killed by an overdose of Nembutal $(50 \mathrm{mg} / \mathrm{rat}$ intravenously). For metaphase arrest in vitro, pieces of intestinal segments were excised from animals killed by an overdose of Nembutal $(50 \mathrm{mg} / \mathrm{rat}$ intracardially). Specimens were cut into smaller pieces and transferred into RPMI 1640 medium gassed with oxygencarbon dioxide $(95: 5, \mathrm{v} / \mathrm{v})$. Colchicine $(3 \mathrm{mg} / \mathrm{l})$ was added at $0 \mathrm{~h}$, and samples were taken after $1.5,2.0$ and $2.5 \mathrm{~h}$. Tissue blocks were fixed in acetic acid ethyl alcohol $(1: 3, \mathrm{v} / \mathrm{v})$ and stained with Feulgen reaction for DNA. Crypts were dissected under a stereomicroscope and squashed on to a glass slide (Wimber \& Lamerton, 1973). Frequencies of metaphase per crypt were counted in twenty crypts per specimen and regressed against the duration of metaphase arrest by the least squares method (pp. 461-469 of Sokal \& Rohlf, 1981). All regressions were statistically significant $(P<0 \cdot 01)$. The slope of the regression line represented the CCPR (Sakata, 1986). The relations were not checked for a non-linear component since only the slope of the linear component was of biological significance.

\section{Expt 1. Time-course study}

Appearance of the trophic effect of SCFA was studied in rats randomly assigned to two groups of fourteen at 7 weeks of age. A $3 \mathrm{ml}$ portion of either SCFA mixture (acetic, propionic and $n$-butyric acids; 100,20 , and $60 \mathrm{~mm}$ respectively) or sodium chloride solution $(180 \mathrm{~mm})$ was injected per fistula twice daily at 10.00 and 16.00 hours. The pH of both solutions was adjusted to 6.1 with sodium hydroxide or hydrochloric acid. The concentrations of SCFA and $\mathrm{pH}$ of the solution were within the range of physiological fluctuation of the caecal contents of rats fed on a commercial diet (MF; see Feeds) ad lib. (T. Yajima and T. Sakata, unpublished results). CCPR of the caecum and distal colon between 12.30 and 14.00 hours was calculated after in vitro metaphase arrest in every two rats randomly selected from each group on days $0,1,2,3,5$ and 7 of administration.

\section{Expt 2. Circadian fluctuation of the effect}

The circadian fluctuation of the effect of SCFA was monitored to confirm that the increase in CCPR by SCFA was not due to a shift in the peak in the circadian fluctuation. Rats were 
randomly assigned to two groups of twelve at 7 weeks of age. Each group was given either a SCFA mixture or $\mathrm{NaCl}$ solution as in Expt 1 for $7 \mathrm{~d}$. Two rats were randomly selected from each group to calculate CCPR at six time-points on the 8th day of the administration (see Table 2, p. 98). The administration at 10.00 hours was avoided in rats in which CCPR between 11.00 and 12.00 hours was calculated. The CCPR of the jejunum and distal colon was calculated after in vivo metaphase arrest.

\section{Expt 3. Effect of SCFA in germ-free rats}

The effect of SCFA in germ-free rats was examined to test if the action of SCFA required bacterial activity. Germ-free rats were randomly assigned to two groups of six at 8 weeks of age. The first group received the SCFA mixture and the second group received the $\mathrm{NaCl}$ solution, as in Expt 1, for $14 \mathrm{~d}$. Both solutions were sterilized before use. The CCPR of the jejunum, caecum, proximal colon and distal colon between 12.00 and 13.00 hours was calculated on the 15 th day of the experiment after in vitro metaphase arrest.

\section{Expt 4. In vivo dose-response study}

Effects of acetic, propionic and $n$-butyric acids were compared in a dose-response study in which thirty rats were randomly assigned to ten groups of three blocks at 7 weeks of age. A control group received no further treatment. The other nine groups were given either acetic, propionic or $n$-butyric acids ( $3 \mathrm{ml}$ twice daily at 10.00 and 16.00 hours) per ileal fistula for $7 \mathrm{~d}$ (see Table 4, p. 99). Test solutions were prepared by mixing one of SCFA stock solutions $(200 \mathrm{~mm}, \mathrm{pH} 6 \cdot 1)$ with $\mathrm{NaCl}$ solution $(200 \mathrm{~mm}, \mathrm{pH} 6 \cdot 1)$. The CCPR of the jejunum and distal colon between 15.00 and 16.00 hours was calculated after in vivo metaphase arrest.

\section{Expt 5. Direct effects of SCFA in vitro}

Effects of SCFA on isolated caecal tissue were examined in a dose-response study. Five rats of 6 weeks of age and weighing 106-121 g were killed by an overdose of Nembutal $(50 \mathrm{mg} /$ rat). Caecal tissue was taken from the caecal body and cut into small pieces (approximately $2 \mathrm{~mm}$ diagonal). Tissue pieces were then cultured in RPMI 1640 medium as described previously, but with the addition of $\mathrm{NaCl}$ or a sodium salt of SCFA (see Table 5, p. 100). Colchicine was added after the pre-incubation with $\mathrm{NaCl}$ or a sodium salt of SCFA for $30 \mathrm{~min}$ for the metaphase arrest in vitro to calculate CCPR.

\section{Statistical treatment}

Calculations were performed using a HP9000 216 computer loaded with HP 98820A statistical program (Hewlett-Packard Co., Fort Collins, USA). Values were analysed by analysis of variance (pp. 321-399 of Sokal \& Rohlf, 1981) after logarithmic transformation to stabilize variance (p. 419-421 of Sokal \& Rohlf, 1981), if necessary (Tables 1-3). Posthoc comparison of means were conducted either by Duncan's test or by Scheffe's test (pp. 137 and 138 of Keppel, 1973) only when the preliminary analysis of variance indicated significant treatment effects. Difference between means were considered significant at $P<0.05$.

\section{RESULTS}

\section{Expt 1. Time-course study}

SCFA increased CCPR both in the caecum $(P<0.0001)$ and distal colon $(P<0.0009)$ (Table 1). The time-course of the effect was essentially similar in both segments. The effect appeared within $1 \mathrm{~d}$ of the treatment in the caecum and within $2 \mathrm{~d}$ in the distal colon. The effect lasted at least until the 7th day of the experiment. 
Table 1. Expt 1. The trophic effect (cells produced/crypt per $h$ ) of short-chain fatty acids (SCFA; acetic 100, propionic 20 and n-butyric acid $60(\mathrm{mM}), \mathrm{pH} 6 \cdot 1,3 \mathrm{ml}$ twice daily per ileal fistula) on the large intestine of rats fed on an elemental diet (Elental ${ }^{\circledast}$ plus kaolin, 9:1 $(w / w))$

(Results are from duplicate observations)

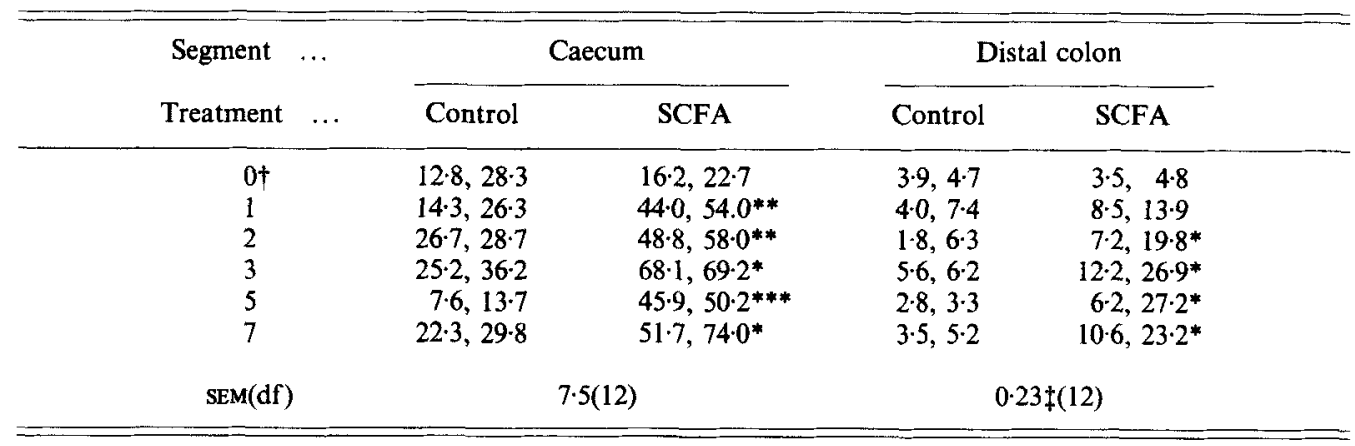

Mean values were significantly different from the control (180 mM- $\mathrm{NaCl}, \mathrm{pH} 6.1)$ by Scheffe's test; $* P<0.05$, ${ }^{* *} P<0.01,{ }^{* * *} P<0.001$. The distal colon data were analysed after logarithmic transformation.

$\dagger$ Period of treatment (d).

$\ddagger$ SEM of log-transformed data.

Table 2. Expt 2. Circadian fluctuation of epithelial cell proliferation (cells produced/crypt per $h$ ) in the intestine of rats given short-chain fatty acids (SCFA; acetic 100, propionic 20 and $n$-butyric acid $60(\mathrm{~mm}), \mathrm{pH} 61,3 \mathrm{ml}$ twice daily per ileal fistula) or sodium chloride ( $180 \mathrm{mM}, \mathrm{pH} 6 \cdot 1,3 \mathrm{ml}$ twice daily; control)

(All animals were fed on an elemental diet (Elental ${ }^{\star}$ plus kaolin, 9:1 (w/w)). Results are from duplicate observations)

\begin{tabular}{ccccccc}
\hline Segment $\ldots$ & \multicolumn{2}{c}{ Jejunum } & & \multicolumn{2}{c}{ Distal colon } \\
\cline { 2 - 5 } Treatment & $\ldots$ & Control & SCFA & & Control & SCFA \\
\hline $11.00-12.00 \dagger$ & $3 \cdot 1,10 \cdot 0^{\mathrm{a}}$ & $26 \cdot 1,31 \cdot 5^{\mathrm{a} * * *}$ & & $1 \cdot 0,1 \cdot 6^{\mathrm{a}}$ & $14 \cdot 7,12 \cdot 0^{\mathrm{b} * * *}$ \\
$15.00-16.00$ & $6 \cdot 2,9 \cdot 9^{\mathrm{a}}$ & $19 \cdot 5,31 \cdot 4^{\mathrm{a} * * *}$ & & $4 \cdot 3,6 \cdot 5^{\mathrm{b}}$ & $10 \cdot 6,11 \cdot 1^{\mathrm{b}}$ \\
$19.00-20.00$ & $9 \cdot 3,11 \cdot 5^{\mathrm{a}}$ & $32 \cdot 0,37 \cdot 9^{\mathrm{a} * * *}$ & & $1 \cdot 4,6 \cdot 7^{\mathrm{ab}}$ & $3 \cdot 5,0^{\mathrm{a}}$ \\
$23.00-24.00$ & $2 \cdot 2,5 \cdot 4^{\mathrm{a}}$ & $27 \cdot 7,29 \cdot 4^{\mathrm{a} * * *}$ & & $1 \cdot 8,5 \cdot 7^{\mathrm{ab}}$ & $7 \cdot 5,11 \cdot 3^{\mathrm{b} *}$ \\
$03.00-04.00$ & $5 \cdot 9,13 \cdot 7^{\mathrm{a}}$ & $30 \cdot 9,43 \cdot 5^{\mathrm{a} * * *}$ & & $3 \cdot 2,6 \cdot 6^{\mathrm{b}}$ & $9 \cdot 1,13 \cdot 6^{\mathrm{b} *}$ \\
$07.00-08.00$ & $6 \cdot 1,9 \cdot 4^{\mathrm{a}}$ & $22 \cdot 6,34 \cdot 1^{\mathrm{a} * * *}$ & & $5 \cdot 5,7 \cdot 6^{\mathrm{b}}$ & $14 \cdot 6,36 \cdot 6^{\mathrm{b} * *}$ \\
& & & & $0 \cdot 50+(12)$ \\
\hline
\end{tabular}

The distal colon data were tested after logarithmic transformation. ${ }^{a, b, c}$ Means within a (segment $\times$ treatment) group not sharing a common superscript letter differed significantly (Duncan's test): $P<0.05$.

Mean values were significantly different from the control (Scheffe's test): ${ }^{*} P<0.05,{ }^{* *} P<0.01$, *** $P<0.001$.

$\dagger$ Time of day $(\mathrm{h})$.

$\ddagger$ SEM of log-transformed data.

Expt 2. Circadian fluctuation of the effect

There was no significant time $\times$ SCFA interaction in the jejunum or distal colon $(P>0.8$ and 0.16 respectively), indicating that SCFA increased the CCPR $(P<0.0001)$ independent of its circadian fluctuation $(P<0.03)$ (Table 2$)$. 
Table 3. Expt 3. Effect of short-chain fatty acids (SCFA; acetic 100, propionic 20 and $n$ butyric acid $60(\mathrm{~mm}), \mathrm{pH} 6 \cdot 1,3 \mathrm{ml}$ twice daily per ileal fistula for $14 \mathrm{~d}$ ) on epithelial cell proliferation (cells produced/crypt per $h$ ) in the intestine of germ-free rats

(Geometric mean values for four rats, SEM of log-transformed data 0.21, df 24)

\begin{tabular}{cccccc}
\hline Segment & $\ldots$ & Jejunum & Caecum & Proximal colon & Distal colon \\
\hline Control $\dagger$ & $3 \cdot 4$ & $4 \cdot 5$ & $2 \cdot 0$ & $1 \cdot 5$ \\
SCFA & $10 \cdot 5^{* *}$ & $9 \cdot 3^{*}$ & $7 \cdot 7^{* * *}$ & $3 \cdot 3^{*}$ \\
\hline \hline
\end{tabular}

Mean values were significantly different from the control mean by Scheffe's test after logarithmic transformation of the data: $* P<0.05, * * P<0.01, * * * P<0.001$.

$\uparrow$ Sodium chloride solution, $180 \mathrm{~mm}$, pH 6.1.

Table 4. Expt 4. Comparison of dose-response relation of three short-chain fatty acids for their effects on epithelial cell proliferation (cells produced/crypt per h) in the intestine of rats fed on an elemental diet (Elental ${ }^{\circledR}$ plus kaolin, 9:1 $(w / w)$ )

(Mean values for three rats)

\begin{tabular}{|c|c|c|c|c|}
\hline Dose: $\operatorname{mM}_{\mathrm{mmol} / \mathrm{d}} \ldots$ & $\begin{array}{l}50 \\
0 \cdot 3\end{array}$ & $\begin{array}{l}100 \\
0 \cdot 6\end{array}$ & $\begin{array}{c}200 \\
1 \cdot 2\end{array}$ & SEM (df) \\
\hline $\begin{array}{l}\text { Jejunum } \\
\text { Acetic } \\
\text { Propionic } \\
n \text {-Butyric } \\
\text { Control* }\end{array}$ & $\begin{array}{c}9 \cdot 5^{\mathrm{ab}} \\
14 \cdot 7^{\mathrm{abc}} \\
16 \cdot 7^{\mathrm{bc}} \\
-\end{array}$ & $\begin{array}{l}12 \cdot 5^{\mathrm{abc}} \\
17 \cdot 6^{\mathrm{c}} \\
18 \cdot 4^{\mathrm{c}} \\
-\end{array}$ & $\begin{array}{c}14 \cdot 7^{\mathrm{abc}} \\
18 \cdot 7^{\mathrm{c}} \\
27 \cdot 2^{\mathrm{d}} \\
9 \cdot 1^{\mathrm{a}}\end{array}$ & $3 \cdot 7(20)$ \\
\hline $\begin{array}{l}\text { Distal colon } \\
\text { Acetic } \\
\text { Propionic } \\
n \text {-Butyric } \\
\text { Control* }\end{array}$ & $\begin{array}{c}4 \cdot 9^{\mathrm{abc}} \\
4 \cdot 6^{\mathrm{ab}} \\
6 \cdot 2^{\mathrm{cd}} \\
-\end{array}$ & $\begin{array}{l}6 \cdot 0^{\text {bed }} \\
4 \cdot 6^{\mathrm{ab}} \\
6 \cdot 6^{\mathrm{d}} \\
\end{array}$ & $\begin{array}{l}6 \cdot 5^{\text {cd }} \\
6 \cdot 0^{\text {bed }} \\
9 \cdot 4^{\text {e }} \\
4 \cdot 6^{\mathrm{a}}\end{array}$ & $0.8(20)$ \\
\hline
\end{tabular}

a, b,c Means in each segment not sharing a common superscript letter differed significantly (Duncan's test): $P<0.05$.

* Sodium chloride solution, $200 \mathrm{~mm}, \mathrm{pH} 6 \cdot 1$.

Expt 3. Effects of SCFA in germ-free rats

SCFA increased the CCPR in the jejunum $(P<0.01)$, caecum $(P<0.05)$, proximal colon $(P<0.001)$ and distal colon $(P<0.05)$ of germ-free rats (Table 3$)$.

Expt 4. In vivo dose-response study

All SCFA, except acetic acid in the jejunum, showed a dose-dependent $(P<0.008)$ stimulatory effect $(P<0.0001)$ on CCPR (Table 4$)$. The effectiveness was in the order $n$-butyric $>$ propionic $>$ acetic acid $(P<0.001$ by Duncan's test).

Expt 5. Direct effects of SCFA in vitro

SCFA depressed the caecal CCPR in vitro (Table 5). A mixture of SCFA in a molar ratio similar to that in Expts 1-3 had an effect equivalent to that of $n$-butyric acid alone. 
Table 5. Expt 5. Influence of short chain fatty acids on epithelial cell proliferation (cells produced/crypt per h) of rat caecum in vitro

( $95 \%$ confidence limits in parentheses)

\begin{tabular}{|c|c|c|c|c|c|}
\hline Dose, mM & 0.01 & 0.1 & $1 \cdot 0$ & $10 \cdot 0$ & $100 \cdot 0$ \\
\hline Control* & $\begin{array}{c}4 \cdot 4 \\
(3 \cdot 1-5 \cdot 7)\end{array}$ & $\begin{array}{c}4.9 \\
(3 \cdot 4-6 \cdot 4)\end{array}$ & $\begin{array}{c}5 \cdot 0 \\
(4 \cdot 2-5 \cdot 8)\end{array}$ & $\begin{array}{c}5 \cdot 4 \\
(4 \cdot 0-6 \cdot 8)\end{array}$ & $\begin{array}{c}7 \cdot 7 \\
(6 \cdot 7-8 \cdot 7)\end{array}$ \\
\hline Acetic & $\begin{array}{c}6 \cdot 1 \\
(5 \cdot 0-7 \cdot 2)\end{array}$ & $\begin{array}{c}4 \cdot 6 \\
(3 \cdot 6-5 \cdot 6)\end{array}$ & $\begin{array}{c}3.8 \\
(1.6-6.0)\end{array}$ & $\begin{array}{c}4 \cdot 9 \\
(3 \cdot 5-6 \cdot 3)\end{array}$ & $\begin{array}{c}1 \cdot 2 \\
(0 \cdot 2-2 \cdot 2)\end{array}$ \\
\hline Propionic & $\begin{array}{c}5 \cdot 7 \\
(3 \cdot 7-7 \cdot 7)\end{array}$ & $\begin{array}{c}5 \cdot 4 \\
(4 \cdot 1-6 \cdot 7)\end{array}$ & $\begin{array}{c}3 \cdot 6 \\
(2 \cdot 0-5 \cdot 2)\end{array}$ & $\begin{array}{c}1 \cdot 4 \\
(0 \cdot 8-2 \cdot 0)\end{array}$ & $\begin{array}{c}2 \cdot 2 \\
(1 \cdot 2-3 \cdot 2)\end{array}$ \\
\hline n-Butyric & $\begin{array}{c}6 \cdot 6 \\
(5 \cdot 2-8 \cdot 0)\end{array}$ & $\begin{array}{c}1.3 \\
(0.9-1 \cdot 7)\end{array}$ & $\begin{array}{c}2.0 \\
(1 \cdot 1-2 \cdot 9)\end{array}$ & $\begin{array}{c}1 \cdot 1 \\
(-0 \cdot 7-2 \cdot 9)\end{array}$ & $\begin{array}{c}1.7 \\
(0.7-2 \cdot 7)\end{array}$ \\
\hline Mixture $\dagger$ & $\begin{array}{c}4 \cdot 0 \\
(2 \cdot 6-5 \cdot 4)\end{array}$ & $\begin{array}{c}0.8 \\
(0 \cdot 3-1 \cdot 3)\end{array}$ & $\begin{array}{c}1 \cdot 7 \\
(0 \cdot 9-2 \cdot 5)\end{array}$ & $\begin{array}{c}1 \cdot 7 \\
(0 \cdot 7-2 \cdot 7)\end{array}$ & $\begin{array}{c}1 \cdot 1 \\
(0 \cdot 3-1 \cdot 9)\end{array}$ \\
\hline
\end{tabular}

* Sodium chloride solution, 0.01-100.0 mM, pH 6.1.

$\dagger$ Acetic, propionic and $n$-butyric acids (molar ratio $5: 1: 3$ ).

\section{DISCUSSION}

Results of Expts 1-4 indicated that the stimulatory effect of SCFA on intestinal epithelial cell proliferation in vivo is substantial and highly reproducible. The good agreement in CCPR values between experiments in the present and previous studies (Wright, 1980; Goodlad \& Wright, 1983; Sakata, 1984, 1986) confirmed the methodological soundness of the present study.

The present results indicated that the effect of SCFA persists sufficiently long to be of nutritional significance. On the basis of the results of Expt 3 (Table 3) and of previous studies (Sakata, 1984, 1986), the effect seems to last for at least $14 \mathrm{~d}$.

The results of the study on the circadian fluctuation (Table 2) confirmed that the increase in CCPR by SCFA (Tables 1, 3 and 4) (Sakata, 1984, 1986) was not due to the modulation of circadian rhythm but actually represented the trophic effect of SCFA. To assess the nutritional significance of this trophic effect daily CCPR (cells produced/crypt per d) was estimated by multiplying mean hourly CCPR (mean of $6 \times 2$ CCPR in $1 \mathrm{~d}$ (Table 2): cells produced per crypt/h) by 24 . Daily CCPR in the jejunum and colon CCPR were $185 v .727$ and 104 v. 293 in control and experimental rats respectively. This suggests that SCFA may have increased daily epithelial cell production three- to fourfold from the level depressed by feeding an elemental diet without fermentable fibre (Goodlad \& Wright, 1983). Such an increase in cell production should accompany an equivalent increase in epithelial cell loss (otherwise, the tissue weight would markedly increase) and in endogenous faecal nitrogen excretion. Considering that $287 \mathrm{~g}(6.5-12 \mathrm{~g}$ protein) of cells are lost every $24 \mathrm{~h}$ from the mucosa of the entire human gastrointestinal mucosa (Croft \& Cotton, 1973), the three- to fourfold increase in epithelial cell loss is likely to be of nutritional significance.

Doses of SCFA in Expts $1-3(1.08 \mathrm{mmol} / \mathrm{d})$ were within daily caecal production levels (10 mmol/d) (Yang et al. 1970), suggesting that SCFA are physiological lumen trophic factors. The trophic effect of SCFA demonstrated in the present experiments in vivo probably explains part of the trophic effects of ingested food (Levine et al. 1974; Janne et al. 1977; Riecken \& Menge, 1977; Ryan et al. 1979; Weser et al. 1982), especially fermentable fibre (Komai et al. 1982; Goodlad et al. 1983; Jacobs \& Lupton, 1984), gut microbes (Meslin et al. 1981; Komai et al. 1982) and lumen contents (Stragand \& Hagemann, 1977; Weser et al. 1982) on the gut epithelium, since all are factors that increase microbial production of SCFA. 
When the concentrations of SCFA used in Expt 4 (Table 4) are compared with the lumen concentrations measured by Yang et al. (1970), it is clear that physiological doses of acetic acid had a trophic effect on colonic epithelium and butyric acid had a trophic effect on both jejunal and colonic epithelium. In contrast, propionic acid was effective only at superphysiological doses. It is not yet known whether the effects of SCFA depend on the concentration or the total daily dose, and whether the effects of each acid depend on the presence of other SCFA. The dose-dependency and interactions among acids found in Expt 4 (Table 4) suggest that the intestinal epithelium may react to factors that alter the amount and molar proportions of SCFA; such factors include the fibre source and composition (Topping \& Illman, 1986) and transit time of digesta in the hind-gut.

However, it is unlikely that SCFA at physiological levels promote epithelial cell proliferation beyond the normal range. The maximum CCPR in Expt 4 (Table 4) was still within the physiological range (Goodlad $e t$ al. 1983) after stimulation with extremely high doses of $n$-butyric acid.

Results from the present study provide a basis on which to discuss the mechanism of the effect of SCFA. Results from Expt 5 (Table 5) confirmed that SCFA inhibit epithelial cell proliferation of the caecal tissue in vitro. Such inhibitory actions agree with results from many other studies (e.g. Ginsburg et al. 1973; Kruh, 1982), including those on primary culture of rumen epithelial cells (Galfi et al. 1981) and human colonic cancer cells (Dexter et al. 1984). The inhibitory effects in vitro and the stimulatory effect on distant gut segments (jejunum) in vivo (Tables 2-4) (Sakata, 1984) suggest that the effect of SCFA in vivo is indirect.

A systemic mediatory mechanism that transmits the stimuli of SCFA to the epithelial cells is proposed for the trophic effect in vivo. This mechanism would be expected to dominate the direct inhibitory action of SCFA. Results from the germ-free rats (Table 3) indicated that the trophic effect of SCFA does not require bacterial action. A specific receptor mechanism for SCFA exists in, or beneath, the mucosa of the digestive tract in ruminants (Leek \& Harding, 1975) and in rats (Yajima, 1985).

Lupton et al. (1985) suggested that the stimulatory effect of low lumen $\mathrm{pH}$ on epithelial proliferation in the large intestine depended on the relation between lumen $\mathrm{pH}$ and the proportion of cells in the $S$ phase of the cell cycle. However, this suggestion was not tested experimentally by lowering lumen $\mathrm{pH}$ by agents other than dietary fibre or SCFA. In addition, low lumen $\mathrm{pH}$ cannot explain the present results, because the $\mathrm{pH}$ of the test solution was adjusted to 6.1. In fact Yajima (1985), by using inorganic acids and SCFAderivatives, demonstrated that the receptor mechanism for SCFA in the rat colon is specific for SCFA and is not sensitive to protons.

Leek \& Harding (1975) showed that a vago-vagal reflex transmits signals from such a receptor mechanism in the ruminant, and the involvement of the autonomic nervous system was suggested in an acute study on epithelial proliferation in rats (Sakata \& von Engelhardt, 1983). However, it is not yet known whether such a mechanism is involved in the chronic trophic effect of SCFA found in the present study.

Humoral mediation may be another candidate. A study in sheep suggested the involvement of insulin in the effect of SCFA (Sakata et al. 1980). However, SCFA do not stimulate insulin release in rats (Horino et al. 1968). The involvement of other humoral trophic factors such as enteroglucagon has yet to be studied. Other effects of SCFA such as the stimulation of mucosal blood flow (Dobson, 1984; Kvietys \& Granger, 1981) and contribution to the energy source of epithelial cells (Roediger, 1982) cannot explain the effect of SCFA in vivo, since the effects of these factors are local. However, they may help to maintain higher proliferative activity.

SCFA seem to belong to a unique category of lumen trophic factors. Sugars and amino 
acids are known lumen trophic factors acting locally in the small intestine (Weser et al. 1982). In contrast, SCFA act physiologically in the large intestine and are mediated via a systemic mechanism. SCFA seem to be involved in a mechanism that transmits information in the hind-gut to distant segments of the digestive tract and possibly to other organs.

The trophic effect of SCFA may benefit the animal by increasing epithelial cell mass and absorptive surface area, thus reducing the load of SCFA in the large intestine. Further, increased epithelial cell production may be required to meet the increased cell loss from abrasion by an increased faecal mass such as would result from an increased supply of fermentable fibre (Topping \& Illman, 1986). However, increased epithelial cell production inevitably requires more protein which cannot be synthesized from SCFA alone. This could be a disadvantage under conditions of marginal protein availability.

The excellent technical assistance of Mrs Hiromi Setoyama for these studies is gratefully acknowledged. The author thanks his colleagues in the laboratory animal facility for their skilled maintainance of the rats. The author is indebted to creative suggestions of Drs I. D. Hume, K. Kato and T. Yajima on this paper.

\section{REFERENCES}

Croft, D. N. \& Cotton, B. (1973). Digestion 8, 144-160.

Dexter, D. D., Lev, R., McKendall, G. R., Mitchell, P. \& Calabres, P. (1984). Histochemical Journal 16, 137-149.

Dobson, A. (1984). Quarterly Journal of Experimental Physiology 69, 599-606.

Galfi, P., Neogrady, S. \& Kutas, F. (1986). Journal of Veterinary Medicine A 33, 47-52.

Galfi, P., Veresegyhazy, T., Neogrady, S. \& Kutas, F. (1981). Zentralblatt für Veterinär Medizin 28A, 259261.

Ginsburg, E., Salamon, D., Sreevalsan, T. \& Freese, E. (1973). Proceedings of the National Academy of Sciences USA 70, 2457-2461.

Goodlad, R. A., Al-Mukhtar, M. Y. T., Ghateri, M. A., Bloom, S. R. \& Wright, N. A. (1983), Virchows Archiv (Cell Pathology) 43, 55-62.

Goodlad, R. A. \& Wright, N. A. (1983). British Journal of Nutrition 50, 91-98.

Horino, M. L., Machlin, J., Hertelendy, F. \& Kipnis, D. M. (1968). Endocrinology 83, $118-128$.

Hoskins, L. C. (1978). In The Glycoconjugates vol. 2, pp. 235-253 [M. I. Horowitz and W. Pigman, editors]. London and New York: Academic Press.

Jacobs, L. R. \& Lupton, J. R. (1984). American Journal of Physiology 246, G378-G385.

Janne, P., Carpentier, Y. \& Willems, G. (1977), Digestive Diseases 22, 808-812.

Keppel, G. (1973). Design and Analysis: $A$ Researcher's Handbook pp. 137-138. Englewood Cliffs: PrenticeHall.

Komai, M., Takehisa, F. \& Kimura, S. (1982). Nutritional Reports International 26, 255-261.

Kruh, J. (1982). Molecular and Cellular Biochemistry 42, 65-82.

Kvietys, P. R. \& Granger, D. N. (1981). American Journal of Physiology 193, 95G-113G.

Leek, B. F. \& Harding, R. H. (1975). In Digestion and Metabolism in the Ruminant, pp. 60-76 [I. W. McDonald and A. C. I. Warner, editors]. Armidale: University of New England Publishing Unit.

Levine, G., Deren, J. J., Steiger, E. \& Zinno, R. (1974). Gastroenterology 67, 975-982.

Lupton, J. R., Coder, D. M. \& Jacobs, L. R. (1985). American Journal of Physiology 249, G382-G388.

Meslin, J. C., Sacquet, E. \& Riottot, R. (1981). Reproduction, Nutrition et Developpment 21, 651-659.

Riecken, E. D. \& Menge, H. (1977). Acta Hepato-Gastroenterologia 24, 389-399.

Roediger, W. E. W. (1982). In Colon and Nutrition, pp. 11-24 [H. Kasper and H. Goebell, editors]. Lancaster: MTP Press.

Ryan, G. P., Dudrick, S. J., Copeland, E. M. \& Johnson, L. R. (1979). Gastroenterology 77, 658-663.

Sakata, T. (1984). Canadian Journal of Animal Science 64, Suppl. 189-190.

Sakata, T. (1986). Journal of Nutritional Sciences and Vitaminology 32, 355-362.

Sakata, T., Hikosaka, K., Shiomura, Y. \& Tamate, H. (1980). British Journal of Nutrition 44, 325-331.

Sakata, T. \& Tamate, H. (1978). Journal of Dairy Science 61, 1109-1113.

Sakata, T. \& Tamate, H. (1979). Journal of Dairy Science 62, 49-52.

Sakata, T. \& von Engelhardt, W. (1983). Comparative Biochemistry and Physiology 74 A, 459-462.

Sakata, T. \& Yajima, T. (1984). Quarterly Journal of Experimental Physiology 69, 639-648.

Sokal, R. R. \& Rohlf, F. J. (1981). Biometry, 2nd ed. San Francisco: Freeman.

Stragand, J. J. \& Hagemann R. N. (1977). American Journal of Physiology 233, E208-E211. 
Tamate, H., McGilliard, A. D, Jacobson, N. L. \& Getty, R. (1962). Journal of Dairy Science 45, 408-420.

Topping, D. L. \& Illman, R. J. (1986). Medical Journal of Australia 144, 307-309.

Umesaki, Y., Yajima, T., Yokokura, T. \& Mutai, M. (1979). Pflügers Archiv 379, 43-48.

Weser, E., Vandeventer, A. \& Tawil, T. (1982). Scandinavian Journal of Gastroenterology 74, Suppl. $105-113$.

Wimber, D. R. \& Lamerton, L. F. (1973). Radiation Research 18, 137-146.

Wright, N. A. (1980). In Cell Proliferation in the Gastrointestinal Tract, pp. 3-21 [D. R. Appleton, J. P. Sunter and A. J. Watson, editors]. Tunbridge Wells: Pitman Medical.

Wright, N. A. \& Appleton, D. R. (1980). Cell and Tissue Kinetics 13, 643-663.

Yajima, T. (1985). Journal of Physiology 368, 667-678.

Yang, M. G., Manoharan, K. \& Mickelsen, O. (1970). Journal of Nutrition 100, 545-550. 